\title{
Detection of Sperm Antigens on Mouse Ova and Early Embryos
}

\author{
Alan C. Menge and Christopher H. Fleming \\ Department of Obstetrics and Gynecology, The University of Michigan, Ann Arbor, Michigan 48109
}

Received July 11, 1977; accepted in revised form November 7, 1977

\begin{abstract}
Serum and colostrum antibodies against mouse sperm were developed in two rabbits after systemic and mammary gland immunizations. Indirect immunofluorescence utilizing fluorescein-labeled goat antisera against rabbit IgG and IgA, respectively, indicated that both immune serum (IS) and colostrum (IC) compared with control samples caused intensive staining of the acrosome and tail of sperm. Absorption of IS and IC with mouse serum and the spleen, kidney, liver, and brain of male mice did not reduce the strength or the pattern of staining reaction on sperm. The absorbed IS reacted with cell surfaces of oocytes, unfertilized ova, zygotes, two-cell and four- to eight-cell fertilized ova, and blastocysts. The absorbed IC, however, reacted only with the four- to eight-cell embryo and blastocyst. Further absorption of the IS with mouse ovary removed the reaction with unfertilized ova and the one- to two-cell fertilized ova, but the staining of later embryo stages was unaffected. Therefore, it appears that specific rabbit anti-sperm antibodies are detecting two cell-membrane antigens on mouse embryos: one originating from the ovary and the other arising after fertilization.
\end{abstract}

\section{INTRODUCTION}

In recent years a number of studies have reported on the antigens of the mouse embryo and cross-reactions with antisera directed against other types of cells and tissues. Antisera raised in male mice of strain 129 against primitive teratocarcinoma cells (PTC) of testicular origin have detected a cell surface antigen (F9 antigen) common to different PTC lines, cleavage embryos, and sperm cells (Artzt et al., 1973). The antigen appeared to be an embryonic antigen as it was not detected on various adult somatic cells and tumors. Further studies, however, indicated its presence on human spermatozoa (Fellous et al., 1974) and all diploid precursors of mouse spermatozoa (Gachelin et al., 1976). In studies using rabbit antisera against strain $129 / \mathrm{J}$ mouse testis teratoma, three antigens were detectable: one was expressed on ova, morulae, and many mouse tumors; another was absent from cleavage embryos but appeared on the trophoblast of the blastocyst; and the last was teratoma specific (Gooding et al., 1976). It was also reported that mouse cerebellum in- duced antiserum in rabbits that cross-reacted with sperm cells, unfertilized and fertilized ova, and preimplanting blastocysts (Solter and Schachner, 1976).

In our own studies on induction of infertility by isoimmunization with spermatozoa in female rabbits and cattle, a significant increase in mortality of preimplanting embryos was noted (Menge, 1970; Menge et al., 1972). Further analysis revealed that rabbit embryos were reactive with anti-sperm isoantibodies of IgA class but not of IgG origin (Menge et al., 1974). Studies in sperm-immunized female mice have generally attributed induced infertility to an inhibition of fertilization (Edwards, 1964; Bell and McLaren, 1970). A recent report, however, suggests that embryo mortality was a major result in mice hyperimmunized with sperm cells (Tung and Goldberg, 1975). Therefore, this study was undertaken to determine whether or not spermatozoa are capable of inducing heterologous antibodies reactive with antigens expressed by the cleavage-stage embryos and blastocysts in random-bred Swiss mice. 
MATERIALS AND METHODS

Rabbit immunization. Sperm cells from the minced epididymides of six mature male Swiss mice were recovered in Hanks' balanced salt solution (HBSS), filtered through cheesecloth, and washed twice in HBSS. The sperm were suspended in $3 \mathrm{ml}$ of HBSS and divided into three equal aliquots of $1 \mathrm{ml}$ each with two aliquots immediately frozen $\left(-20^{\circ} \mathrm{C}\right)$. The $1-\mathrm{ml}$ sperm suspension was mixed with $1 \mathrm{ml}$ of Freund's complete adjuvant. Two female New Zealand White rabbits were each injected with $1 \mathrm{ml}$ of the mixture at multiple subcutaneous and intramuscular sites. The rabbits received a second injection 2 weeks later with the third injection following in 3 weeks for one of the rabbits. Control serum samples were obtained before injection and immune sera (IS) at 7 and 14 days postinjection. The second rabbit was mated 3 weeks following the second injection and given intramammary gland injections of $0.5 \mathrm{ml}$ of the spermadjuvant mixture at 10 and 20 days of pregnancy. Starting the second day after parturition and once daily for 3 days, colostrum was obtained from the locally immunized rabbit by manual milking of the mammary glands. The immune colostrum (IC) samples were pooled and clarified by centrifugation at $40,000 \mathrm{~g}$ for $2 \mathrm{hr}$. Control colostrum was obtained in similar manner from an untreated rabbit.

Absorption of the control and immune serum and colostrum samples was done by adding mouse normal serum (MNS) to $20 \%$ of the rabbit sample volume, twice with an equal volume of packed spleen, liver, and kidney homogenate (SnLK) and twice with an equal volume of packed brain homogenate from male mice. Epididymal sperm and testis homogenate were also used for absorptions. The tissue homogenates were prepared by mincing the organs in phosphate-buffered saline (PBS, $\mathrm{pH}$ 7.5), gentle homogenization with a ground-glass tissue homogenizer, and repeated washings with PBS by centrifuga- tion until the supernatants were clear. Absorption was done at $37^{\circ} \mathrm{C}$ for $30 \mathrm{~min}$ and overnight at $5^{\circ} \mathrm{C}$ followed by centrifugation $(17,500 \mathrm{~g})$ for $20 \mathrm{~min}$ at $2^{\circ} \mathrm{C}$. The absorbed samples were dialyzed extensively against PBS for 2 days after which, if the samples appeared cloudy or had a precipitate, they were centrifuged.

Ova and embryos. Recovery of unfertilized ova was done on the morning after induction of superovulation by chorionic gonadotropin in mice primed with pregnant mare's serum (PMS) after the method of Gates (1971). Cleavage stages and blastocysts were obtained from untreated or superovulated mice after mating and observance of copulatory plug (Day 1). The oviducts were either flushed or minced with HBSS containing 5\% MNS (decomplemented by heating at $56^{\circ} \mathrm{C}$ for $30 \mathrm{~min}$ ) to recover ova, and the uteri were flushed to recover blastocysts. Cumulus cells, when present, were removed by treating ova with hyaluronidase $(100 \mathrm{IU} / \mathrm{ml})$ in HBSS, and the zona pellucida was removed by a brief exposure to $0.25 \%$ Pronase in HBSS and manipulation with a glass micropipet. The zona-free ova and blastocysts were then washed in several changes of HBSS-MNS at room temperature before treatment with antibodies.

Indirect immunofluorescence. The ova and embryos were incubated in the different sera and colostrum samples that were diluted approximately $1: 2.5$ and $1: 10$ with HBSS-MNS medium. Incubation was in a moist chamber for $30 \mathrm{~min}$ at $37^{\circ} \mathrm{C}$ followed by three washes in medium and then incubation for $20 \mathrm{~min}$ at $37^{\circ} \mathrm{C}$ in goat antirabbit IgA and IgG globulin preparations conjugated with fluorescein isothiocyanate. The ova and embryos were washed twice more with HBSS-MNS and then observed under dark-field illumination with a Zeiss microscope equipped with a halogen-quartz light system and appropriate FITC and BG-38 filters. Observations were based on a total of 16 to 32 ova or embryos in two to four replicates per treat- 
ment group.

Mouse spleen cells were subjected to similar methods for immunofluorescence except the reactions proceeded in culture tubes. Indirect immunofluorescence study of mouse epididymal sperm was performed on methanol fixed smears as previously described for human spermatozoa (Johnson and Menge, 1974).

In this study the use of the terms IS and IC refers to rabbit anti-sperm antibodies of the $\operatorname{IgG}$ and $\operatorname{Ig} A$ classes, respectively. The IS did not contain detectable anti-sperm antibodies of the IgA class by indirect immunofluorescence using the conjugated goat anti-IgA globulin. The anti-IgA globulin was absorbed with lyophilized $7 \mathrm{~S}$ globulin of rabbit serum to prevent reaction with the light chains of IgG.

\section{RESULTS}

Indirect immunofluorescence of sperm cells. Compared with weak sperm staining at dilution of 1:5 for control serum and colostrum, the IS and IC samples at dilutions of 1:40 gave strong reactions with the acrosome and tail of the sperm and weaker staining of the postacrosomal area of the sperm head (Fig. 1). None of the absorptions of the IS and IC samples with mouse serum and somatic tissues caused a significant reduction of staining intensity or a change in staining pattern. At 1:5 dilution the labeling was negative for absorbed control serum and colostrum. Absorption, however, with twice the volume of packed sperm cell and testis homogenate completely removed the immunofluorescent reactions of IS and IC diluted 1:10 or greater.

Indirect immunofluorescence on spleen cells, ova, and embryos. Both the normal and immune serum and colostrum samples reacted with spleen cells and unfertilized ova (Table 1). Absorption with mouse serum and somatic tissues removed this reaction from control serum and colostrum and IC but IS continued to react with the unfertilized ova. The reaction seen was a membrane staining. Dilution of unabsorbed control serum to greater than 1:10 gave a negative reaction with spleen cells and ova, whereas the IS still reacted strongly at 1:20.

Although the absorbed IS reacted with the membranes of oocytes, unfertilized ova, zygotes, cleaving fertilized ova, and blastocysts the absorbed IC stained only blastocysts and cleaving embryos starting at the four-cell stage, (Figs. 2, 3, and 4).

A small aliquot $(0.2 \mathrm{ml})$ of absorbed IS and IC was diluted $1: 2$ and then further absorbed with approximately $200 \mathrm{mg}$ of fresh homogenized ovarian tissue from PMS-treated mice. This absorption resulted in a removal of the antibodies in IS that had reacted with unfertilized ova and one- and two-cell fertilized ova. Both the IS and IC continued to cause immunofluorescent staining of four- and eight-cell embryos and blastocysts. Absorption with brain tissue did not reduce the staining of unfertilized ova by IS or cause a significant reduction in staining intensity of four-cell embryos and blastocysts by IS and IC previously absorbed with serum, somatic tissues, and ovary.

Negative reactions were obtained on the ova and embryos using the IS and IC absorbed with sperm cells and homogenized testis tissue.

\section{DISCUSSION}

The use of goat monospecific antisera against rabbit IgA and IgG allowed us to study the reactions of rabbit anti-mouse sperm antibodies of these two Ig classes in colostrum and serum, respectively, against sperm and developing embryos of the mouse by indirect immunofluorescence. IgA antibodies against sperm were not detected in IS but antibodies of both classes were detected in IC. However, we studied only the IgA class of antibodies from IC. Rabbit control serum and colostrum reacted at low dilutions ( $\leq 1: 5)$ with the acrosomes of sperm cells probably be- 

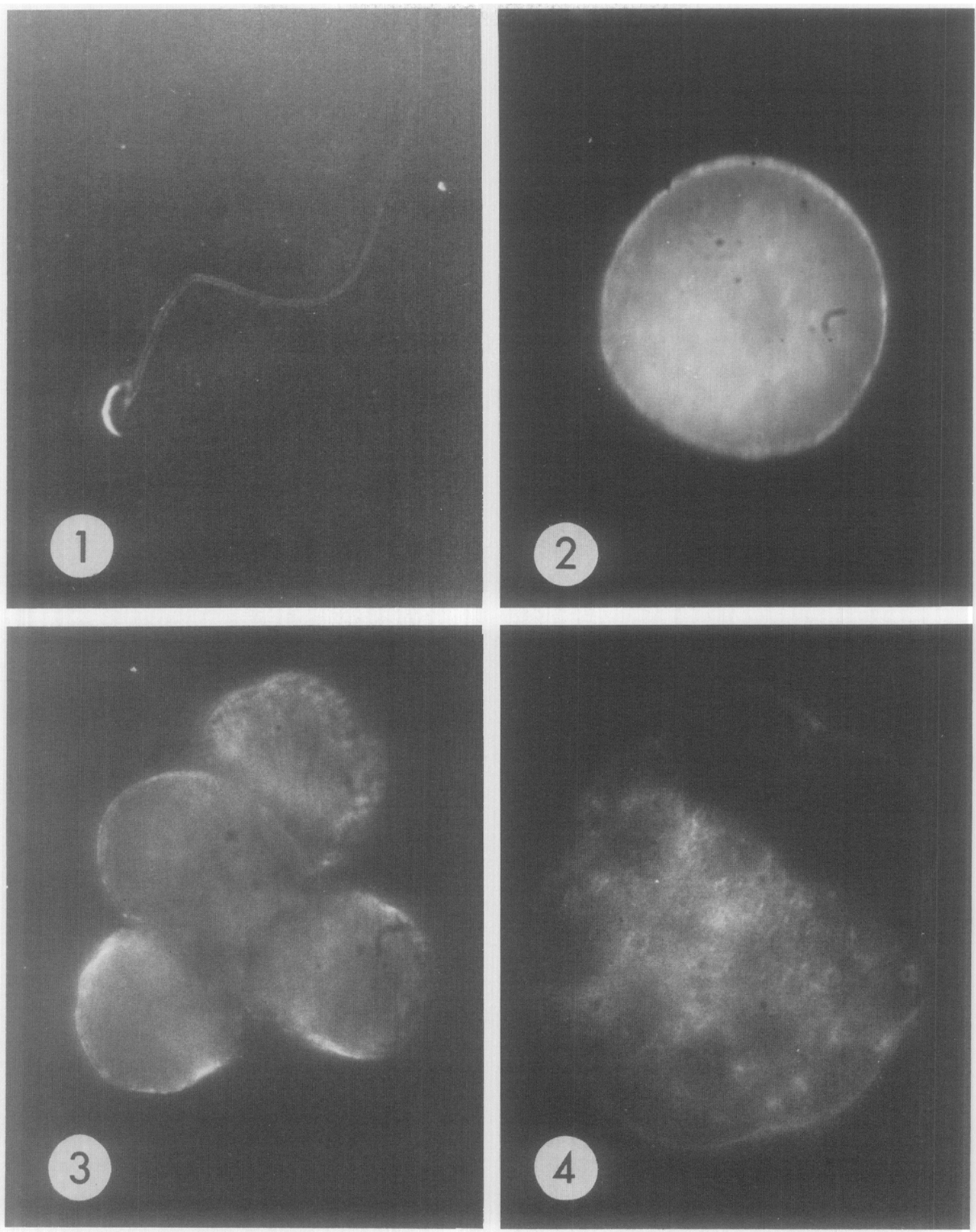

FIGs. 1-4. Indirect immunofluorescent method using fluorescein-labeled goat anti-rabbit IgG globulin after reaction with rabbit immune serum (IS) against mouse epididymal spermatozoa. Approximate magnification, $\times 900$. Figure 1, sperm cell treated with IS (1:20 dilution); Fig. 2, oocyte reacted with IS absorbed with mouse serum (S), spleen (Sn), kidney (K), and liver (L); Fig. 3, four-cell embryo reacted with IS absorbed with mouse S, Sn, K, L, and ovary; Fig. 4, Blastocyst (Day 4) treated with IS absorbed with mouse S, Sn, K, L, and ovary. 
TABLE 1

INDIRECT IMMUNOFLUORESCENCE ON MOUSE Cells ${ }^{a}$

\begin{tabular}{|c|c|c|c|c|c|c|}
\hline \multirow[t]{2}{*}{ Samples $^{b}$} & \multirow{2}{*}{$\begin{array}{l}\text { Spleen } \\
\text { cells }\end{array}$} & \multirow{2}{*}{$\begin{array}{l}\text { Unfertilized ova } \\
\text { and oocytes }\end{array}$} & \multicolumn{3}{|c|}{ Fertilized ova (cells) } & \multirow{2}{*}{$\begin{array}{l}\text { Blasto- } \\
\text { cysts }\end{array}$} \\
\hline & & & 1 & 2 & $4-8$ & \\
\hline HBSS & - & - & - & - & - & - \\
\hline \multicolumn{7}{|l|}{ Unabsorbed } \\
\hline $\mathrm{CS}$ & + & + & + & + & + & + \\
\hline IS & + & + & + & + & + & + \\
\hline $\mathrm{CC}$ & \pm & \pm & \pm & - & - & - \\
\hline IC & + & + & + & + & + & + \\
\hline \multicolumn{7}{|c|}{ Absorbed (SSnLK) } \\
\hline $\mathrm{CS}$ & - & - & - & - & - & - \\
\hline IS & - & + & + & + & + & + \\
\hline $\mathrm{CC}$ & - & - & - & - & - & - \\
\hline IC & - & - & - & - & + & + \\
\hline \multicolumn{7}{|c|}{ Absorbed (SSnLKO) } \\
\hline IS & ND & - & - & - & + & + \\
\hline IC & ND & - & - & - & + & + \\
\hline \multicolumn{7}{|c|}{ Absorbed (SSnLKB) } \\
\hline IS & ND & + & + & + & + & + \\
\hline IC & ND & - & - & - & + & + \\
\hline \multicolumn{7}{|c|}{ Absorbed (sperm, testis) } \\
\hline $\mathrm{CS}$ & - & - & - & - & - & - \\
\hline IS & - & - & - & - & - & - \\
\hline IC & - & - & - & - & - & - \\
\hline
\end{tabular}

${ }^{a}$ Goat anti-rabbit IgA conjugate used with HBSS and colostrum samples; goat anti-rabbit IgG conjugate used with HBSS and serum samples. Abbreviations: ND, not done; CS, control serum; IS, immune serum; IC, immune colostrum; L, liver; O, ovary; S, serum; Sn, spleen; CC, control colostrum; HBSS, Hanks' balanced salt solution; $\mathrm{K}$, kidney; B, brain.

${ }^{b}$ Results expressed as follows: - is negative reaction at dilution $\geq 1: 2.5, \pm$ is positive reaction at $1: 2.5$ dilution but negative at 1:10 dilution; and + is positive reaction at dilution $\geq 1: 10$.

cause of binding either by $\gamma$-globulins nonspecifically or by naturally occurring antibodies. This reaction was removed by absorption with mouse serum and somatic tissues, whereas absorption of IS and IC had little effect on the staining pattern or intensity even at higher dilutions (1:40 to 1:80). The acrosome and tail were intensely stained whereas the postacrosomal cap stained at lower dilutions ( $\leq 1: 10)$ and only by IS. Cell membranes of spleen cells, oocytes, unfertilized ova, fertilized ova, and blastocysts all showed fluorescent labeling after treatment with either control serum or IS before absorption. Absorption of the sera with mouse serum and the somatic tissues removed the natural antibody or the nonspecific binding of $\gamma$-globulins as well as any induced antibody against somatic cells as staining was negative for spleen cells. After absorption, however, the IS continued to label oocytes as well as fertilized ova and blastocysts. IC, on the other hand, after absorption stained only embryos beyond the two-cell stage. The absorption of the IS with ovary removed the staining of oocytes and oneand two-cell fertilized ova but not that of later cleavage stages and blastocysts. The results therefore suggest the IS, namely, IgG antibody as IgA antibody was undetectable in serum, detected at least two cross-reacting antigens: one from ovary and one arising after fertilization at the four- to eight-cell stage. The possibility exists that the latter antigen(s) is present at earlier stages but due to the method used we failed to detect it.

Whereas $\mathrm{H}-2$ transplantation antigens have not been detected on preimplantation embryos (Johnson, 1975) some non-H-2 transplantation antigens have been found 
on embryonic cells from the two-cell stage onward (Palm et al., 1971; Muggleton-Harris and Johnson, 1976). It is unlikely that the antigens we are detecting are either $\mathrm{H}-2$ or paternal antigens as the immune samples were absorbed with pooled tissues from male mice, although to eliminate completely any involvement of transplantation antigens the study should be repeated within an isogenic strain of mice.

Gooding and Edidin (1974) using a rabbit antiserum to mouse testicular teratomas detected three antigens, one of which was found on unfertilized ova and embryos but not in normal testis tissue. Sperm cells, apparently, were not used either for absorption or antibody detection. The syngeneic antisera against PTC cells were reported to label mouse sperm specifically in the postacrosomal region as well as cleavage-stage embryos (Artzt et al., 1973; Fellous et al., 1974). A recent report (Artzt and Hamburger, 1976) suggests the antigen detected by anti-PTC sera also exists on oocyte membranes prior to fertilization. There is a similarity between this antigen and the one detected by our anti-sperm IgG antibody as it is found on oocytes, embryos, and sperm. But our antisera labeled the postacrosomal area of sperm only weakly and this did not change noticeably after absorption with ovary which did remove the oocyte-membrane label.

Presumably, the second sperm antigen that we detected at the four- to eight-cell embryo stage of cleavage is determined by the sperm genome, although delayed replication of the antigen(s) contributed by the sperm membrane after its incorporation into the membrane of the oocyte at fertilization could result in the antigen appearing after the second or third cleavage. This may be the sperm antigen(s) that is capable of inducing the isoantibody or immune response in female mice resulting in the embryo loss reported by Tung and Goldberg (1975). Lerum and Goldberg (1974) found an increased incidence of embryo loss in mice passively immunized during the preimplantation period with antiserum against the sperm-specific LDH-X antigen. In a closely related species, the rat, Isojima (1973) reported finding sperm antigens by an immunofluorescent method on the membranes of fertilized ova and blastocysts. Kometani and Behrman (1971) observed a high incidence of embryo death after passive immunization of pregnant mice with antiplacental sera. Wiley and Calarco (1975) found that antiplacental serum detected antigens from the prefertilization stage onward but did not inhibit development of embryos cultured in vitro. Anti-blastocyst serum, however, detected postfertilization antigens only and especially after the four-cell stage. This antisera also inhibited the development of cultured embryos.

In conclusion, the cellular membranes of mouse oocytes and fertilized ova after the four-cell stage through preimplantation blastocysts possess antigens cross-reactive with epididymal sperm that could render them susceptible to effects by antibodies against sperm cells.

This work was supported by Grant No. HD05200, National Institute of Child Health and Human Development, DHEW

\section{REFERENCES}

Artzt, K., and Hamburger, L. (1976). Embryonic surface antigens: A "quasi-endodermal" teratoma antigen. Develop. Biol. 51, 152-157.

Artzt, K., Dubois, P. H., Bennett, D., CondaMine, H., Babinet, C., and JaCOB, F. (1973). Surface antigens common to mouse cleavage embryos and primitive teratocarcinoma cells in culture. Proc. Nat. Acad. Sci. USA 70, 2988-2992.

Bell, E. B., and McLaren, A. (1970). Reduction of fertility in female mice isoimmunized with a sub-cellular sperm fraction. J. Reprod. Fert. 22, 345-356.

Edwards, R. G. (1964). Immunological control of fertility in female mice. Nature (London) 203, 5053.

Fellous, M., Gachelin, G., Buc-Caron, M. H., DuBors, P., and $J_{A C O B}, F$. (1974). Similar location of an early embryonic antigen on mouse and human spermatozoa. Develop. Biol. 41, 331-337.

Gachelin, G., Fellous, M., Guenet, J. L., and $J_{A C O B}, F$. (1976). Developmental expression of an 
early embryonic antigen common mouse spermatozoa and cleavage embryos, and to human spermatozoa: Its expression during spermatogenesis. Develop. Biol. 50, 310-320.

Gates, A. H. (1971). Maximizing yield and developmental uniformity of eggs. In "Methods in Mammalian Embryology" (Joseph C. Daniel, Jr., ed.), pp 64-75. W. H. Freeman, San Francisco.

Gooding, L. R., and Edidin, M. (1974). Cell surface antigens of a mouse testicular teratoma. J. Exp. Med. 140, 61-78.

Gooding, L. R., Hsu, Y. C., and Edidin, M. (1976). Expression of teratoma-associated antigens on murine ova and early embryos. Develop. Biol. 49, 479-486

IsoJIMA, S. (1973), Antigenicity of fertilized eggs. In "Immunology of Reproduction," Proceedings of the 2nd Symposium of the Sofia Bulgaria Academy of Science, pp. 471-473.

Johnson, W. L., and Menge, A. C. (1975). Evaluation of human sera for antibodies against sperm by immunofluorescence. Fert. Steril. 26, 721-729.

Johnson, M. H. (1975). Fertilization and implantation. In "Immunology of Reproduction" (J. S. Scott and W. R. Jones, eds.), pp 33-50. Academic Press, New York.

Kometani, K., and Behrman, S. J. (1971). The time of onset of placental susceptibility in mice to heterologous anti-mouse placental serum. Int. $J$. Fert. 16, 139-143.

Lerum, J. E., and GoldberG, E. (1974). Immunological impairment of pregnancy in mice by lactate dehydrogenase-X. Biol. Reprod. 11, 108-115.
Menge, A. C. (1970). Immune reactions and infertility. J. Reprod. Fert. Suppl. 10, 171-186.

Menge, A. C., Burkons, D. M., and Friedlaender, G. E. (1972). Occurrence of embryo mortality in rabbits isoimmunized against semen. Int. J. Fert. 17, 93-96.

Menge, A. C., Rosenberg, A., and Burkons, D. M. (1974). Effects of uterine fluids and immunoglobulins from semen-immunized rabbits on rabbit embryos cultures in vitro. Proc. Soc. Exp. Biol. Med. 145, 371-378.

Muggleton-Harris, A. L., and Johnson, M. H. (1976). The nature and distribution of serologically detectable alloantigens on the preimplantation mouse embryo. J. Embryol. Exp. Morphol. $35,59-72$.

Palm, J., Heyner, S., and Brinster, R. L. (1971). Differential immunofluorescence of fertilized mouse eggs with $\mathrm{H}-2$ and non-H-2 antibody. $J$. Exp. Med. 133, 1282-1293.

Solter, D., and Schachner, M. (1976). Brain and sperm cell surface antigen (NS-4) on preimplantation mouse embryos. Develop. Biol. 52, 98-104.

Tung, S. K. K., and Goldberg, E. H. (1975). Immunobiological consequence of immunization of female mice with homologous spermatozoa: Induction of infertility. In "Third International Symposium on Immunology of Reproduction," Varna, Bulgaria, pp 145-146.

Wiley, L. M., and Calarco, P. G. (1975). The effects of anti-embryo sera and their localization on the cell surface during mouse preimplantation development. Develop. Biol. 47, 407-418. 